\title{
Spreading of prions from the immune to the peripheral nervous system: a potential implication of dendritic cells
}

\author{
Gauthier Dorban · Valérie Defaweux • Ernst Heinen • \\ Nadine Antoine
}

Accepted: 2 March 2010

(C) Springer-Verlag 2010

\begin{abstract}
The implication of dendritic cells (DCs) in the peripheral spreading of prions has increased in the last few years. It has been recently described that DCs can transmit prions to primary neurons from the central nervous system. In order to improve the understanding of the earliest steps of prion peripheral neuroinvasion, we studied, using an in vitro model, the effect of exposing primary peripheral neurons to scrapie-infected lymphoid cells. Thanks to this system, there is evidence that bone marrow dendritic cells (BMDCs) are in connection with neurites of peripheral neurons via cytoplasmic extensions. BMDCs are competent to internalize prions independently from the expression of cellular prion protein $\left(\mathrm{PrP}^{\mathrm{C}}\right)$ and have the capacity to transmit detergent-insoluble, relatively proteinase K-resistant prion protein $\left(\mathrm{PrP}^{\mathrm{Sc}}\right)$ to peripheral neurons after $96 \mathrm{~h}$ of coculture. Furthermore, we confirmed the special status of the peripheral nervous system in front of prion diseases.
\end{abstract}

Electronic supplementary material The online version of this article (doi:10.1007/s00418-010-0687-9) contains supplementary material, which is available to authorized users.

G. Dorban $(\bowtie) \cdot$ V. Defaweux $\cdot$ E. Heinen

Human Histology, Immunology Center,

Faculty of Medicine, University of Liège, C.H.U.,

Avenue de l'hôpital, Tour de pharmacie +4, 4000 Liège, Belgium

e-mail: gauthier.dorban@uni.lu

G. Dorban

Life Sciences Research Unit, Faculty of Science,

Technology and Communication, University of Luxembourg,

Campus Limpertsberg, 162a, avenue de la Faïencerie,

1511 Luxembourg, Luxembourg

\section{N. Antoine}

Department of Morphology-Pathology,

Animal Histology, Faculty of Veterinary Medicine,

University of Liège, Boulevard de Colonster, 4000 Liège, Belgium
Contrary to central neurons, $\mathrm{PrP}^{\mathrm{Sc}}$ infection does not disturb survival and neurite outgrowth. Our model demonstrates that $\mathrm{PrP}^{\mathrm{Sc}}$-loaded dendritic cells and peripheral nerve fibers that are included in neuroimmune interfaces can initiate and spread prion neuroinvasion.

Keywords Prions $\cdot$ Dendritic cells $\cdot$ Peripheral nervous system $\cdot$ Neuroinvasion

\section{Introduction}

Prion leads to severe neurodegenerative diseases in a large number of animals as well as in humans. At the biochemical level, these diseases are characterized by the conversion of a normal cellular prion protein, $\operatorname{PrP}^{\mathrm{C}}$, into an abnormal isoform, $\operatorname{PrP}^{\mathrm{Sc}}$, which is enriched by $\beta$-structures and is partially resistant to proteinase $\mathrm{K}$ (Cohen and Prusiner 1998). Prion-affected nervous tissues show accumulation of $\mathrm{PrP}^{\mathrm{Sc}}$, neuronal vacuolization and cell death in the central nervous system (CNS) (Bruce et al. 1989).

Following peripheral infection in various animal models, the sequential detection of abnormal prion protein in lymphoreticular tissues and subsequently along neural projections to the CNS has led to the conclusion that these tissues are implicated in the spread of prion agent to the CNS (Kratzel et al. 2007).

In natural and experimental diseases, the first neural tissues in which $\mathrm{PrP}^{\mathrm{Sc}}$ can be highlighted both in sheep and mice scrapie, cattle bovine spongiform encephalopathy (BSE) and deer chronic wasting disease (CWD) is the enteric nervous system (ENS) of the gut (Andreoletti et al. 2000; van Keulen et al. 2000; Sigurdson et al. 2001; Iwata et al. 2006). This intramural nervous system is composed of two networks, the submucosal and the myenteric plexi, 
which contain the neuronal cell bodies and their processes. It is likely that prion infection of the ENS occurs within fine nerve fibers directly underneath the villous or crypts epithelium (Jeffrey et al. 2006). It is also possible that transmissible spongiform encephalopathy (TSE) agents are transported through the epithelium of the Peyer's patches (Defaweux et al. 2005). Then, prions migrate asymptomatically along the peripheral nervous system (PNS), by axonal anterograde and retrograde transport mechanisms via the vagus and splanchnic nerve (van Keulen et al. 2002), and reach the CNS, where they induce the clinical signs of the disease.

Up to now, the mechanism responsible for ENS infection has not been defined yet. Recent studies have pointed out the potential implication of dendritic cells, a highly migrating cell type localized in the gut lamina propria and mesenteric lymphoid tissues, in the uptake of $\operatorname{PrP}^{\mathrm{Sc}}$ (Kelsall and Rescigno 2004). The role of DCs in prion disease appears to be ambiguous. Some authors have shown, through in vitro models, that DCs can impair prion dissemination and that they are able to process $\mathrm{PrP}^{\mathrm{Sc}}$, by cysteine protease, and to decrease the amount of infectivity associated with scrapie (Luhr et al. 2002, 2004) or BSE (Rybner-Barnier et al. 2006). Several studies have demonstrated that DCs act in the spreading of prions. They appear to be implicated in the uptake of $\operatorname{PrP}^{\mathrm{Sc}}$. Peyer's patches dendritic cells of the suprafollicular dome seem capable of capturing pathogenic prions, especially the CD11c/CD11b DC subset (Dorban et al. 2007b), either by direct uptake across the follicular-associated epithelium, or after that $\mathrm{PrP}^{\mathrm{Sc}}$ has been internalized by $\mathrm{M}$ cells (Heppner et al. 2001; Huang et al. 2002).

The DCs are also implicated in the neuroinvasion process. The first convincing evidence appeared in a study stressing that $\mathrm{PrP}^{\mathrm{Sc}}$-loaded DCs isolated from infected mice are able, and sufficient, to induce scrapie in Rag mice, without any accumulation of prions in the spleen, after an intraperitoneal challenge (Aucouturier et al. 2001). Moreover, DCs seem to disseminate $\operatorname{PrP}^{\mathrm{Sc}}$ to peripheral sites of neuroinvasion such as mesenteric lymphoid tissues (Huang and MacPherson 2004) and the spleen (Blattler et al. 1997). Recent studies have demonstrated that the temporary depletion of dendritic cell impaired neuroinvasion following oral inoculation (Raymond et al. 2007) and intraperitoneal infection (Cordier-Dirikoc and Chabry 2008). An up-todate in vitro study has shown that infected dendritic cells are able to transmit prions to primary neurons from the CNS by the intermediary of tunneling nanotubes (TNT) (Gousset et al. 2009). Previously we have also demonstrated that CD11c-DCs established a lot of contacts with the nerve fibers inside the mouse Peyer's patches in physiological conditions and following a scrapie challenge (Defaweux et al. 2005; Dorban et al. 2007a). Similar results have been obtained within sheep Peyer's patches (Marruchella et al. 2007; Chiocchetti et al. 2008). The molecular basis of these neuroimmune interfaces between DCs and PNS could implicate a ligand-receptor connection via the muscarinic acetylcholine M2 receptor (Ma et al. 2007) or involve TNT (Gousset et al. 2009).

The aim of this study, using an infectious coculture system, focused on the ability of dendritic cells and autonomic neurons to accumulate prions and the impact of prion infection on the development of neurites by primary neurons isolated from the PNS. We also investigated the capacity of BMDCs and peripheral nerve fibers to establish cell-to-cell contacts and the proficiency of dendritic cells in transmitting $\mathrm{PrP}^{\mathrm{Sc}}$ to the PNS. These findings give an insight concerning the implication of DCs in the earliest steps of prion neuroinvasion.

\section{Materials and methods}

Generation of bone marrow dendritic cells (BMDCs)

DCs were generated from BMDCs isolated from C57B1/6 mice or $\mathrm{PrP}^{-/-}$mice, as previously described (Berthier et al. 2000). In short, bone marrow (BM) cells were isolated by flushing cells from the mouse femurs. Erythrocyte cells and $\mathrm{Gr}^{+}$cells were removed by magnetic cell sorting. Negatively selected cells were cultured at $5 \times 10^{5}$ cells $/ \mathrm{mL}$ in complete Iscove's modified Dulbecco's medium (IMDM) (Gibco) supplemented with 1\% of the GM-CSFtransfected J558 cell line supernatant, $40 \mathrm{ng} / \mathrm{mL}$ recombinant Flt3-lg, and $5 \mathrm{ng} / \mathrm{mL}$ mouse recombinant IL-6. $5 \times 10^{5}$ cells $/ \mathrm{mL}$ were resuspended in complete IMDM every 3 days. By day 6, IL-6 was removed and Flt3-lg was used at $20 \mathrm{ng} / \mathrm{mL}$. By day $8-9$ of culture, $90 \%$ of cells demonstrated characteristic DC morphology and phenotype. BMDCs were exploitable from day 9 of the primo-culture up to day 18. During this period of time, the culture was mainly made up of immature BMDCs with the phenotype of differentiated DCs representative of the in vivo population. Cells were deposited on coverslips coated with $50 \mu \mathrm{L}$ $(0.1 \mathrm{mg} / \mathrm{mL})$ of PORN (Sigma) at $37^{\circ} \mathrm{C}$ for $45 \mathrm{~min}$ and were rinsed twice before introducing $50 \mu \mathrm{L}(10 \mu \mathrm{g} / \mathrm{mL})$ of laminin (ICN Biomedicals) at $4^{\circ} \mathrm{C}$ for $24 \mathrm{~h}$. The development of contacts between BMDCs cultured on coverslips was checked twice a day from the 6th to the 96th hour.

Isolation of peripheral neurons

Vertebral columns of C57B1/6 mice were dissected and the dorsal root ganglia (DRGs) were further processed, as described below, to dissociate sensory neurons. Spines were sliced and fragments were conserved in PBS-glucose $(1.5 \mathrm{~mL}$ at $30 \%$ with $100 \mathrm{~mL}$ of sterile-PBS). Nervous ganglia were dissected twice under sterile conditions and incubated 
with $1 \mathrm{~mL}(5 \mathrm{mg} / \mathrm{mL})$ of collagenase A (Roche) at $37^{\circ} \mathrm{C}$ for $45 \mathrm{~min} .1 \mathrm{~mL}$ of trypsin (Bio-Whittaker) at $0.25 \%$ was added for $30 \mathrm{~min}$. Enzymatic digestion was stopped with $500 \mu \mathrm{L}$ of FCS (Perbio Hyclone) and cells were centrifuged at $755 \times g$ for $5 \mathrm{~min}$. The supernatant was removed and the pellet was suspended in a neuron complete medium containing: RPMI $1640+$ L-glutamine (Gibco), $1 \% \mathrm{Na}$ pyruvate (Cambrex), $15 \mu \mathrm{L} / \mathrm{mL}$ of glucose $30 \%$ (Merck), $2.5 \mu \mathrm{L} / \mathrm{mL}$ of insulin (Sigma) and $5 \mu \mathrm{L} / \mathrm{mL}$ of N2 (Invitrogen). After two successive mechanical dissociations using glass Pasteur pipettes, suspended cells were introduced into an equal quantity of Percoll (Sigma) at $26 \%$ and were centrifuged at $2,096 \times \mathrm{g}$ for $12 \mathrm{~min}$. The cell pellet was diluted in $500 \mu \mathrm{L}$ of medium and conserved at $4^{\circ} \mathrm{C}$. The growth of neurites from peripheral neurons cultured on coated coverslips was checked twice a day from the 6th to the 96th hour.

\section{Coculture of BMDCs with neurons}

The number of each cell type, introduced into the coculture, was calculated to obtain the morphology closest to the in vivo situation. Thus, on each coverslip, 200 neurons and $10,000 \mathrm{BMDC}$ were cultured in $50 \mu \mathrm{L}$ of medium at $37^{\circ} \mathrm{C}$ for $60 \mathrm{~min}$. Then $400 \mu \mathrm{L}$ of the coculture complete medium, based on the specific medium of BMDCs and enriched with nutrients essential for neurons (91.4\% of IMDM (Gibco), $6 \%$ of SVF, $1 \%$ of NEAA, $1 \%$ of Na pyruvate, $0.1 \%$ of $\beta$-mercaptoethanol, $0.5 \%$ of penicillin-streptomycin, 60 $\mu \mathrm{L} / \mathrm{mL}$ of GM-CSF, $20 \mathrm{ng} / \mathrm{mL}$ of Flt3-lg, $15 \mu \mathrm{L} / \mathrm{mL}$ of glucose $30 \%, 2.5 \mu \mathrm{L} / \mathrm{mL}$ of insulin at $500 \mu \mathrm{g} / \mathrm{mL}$ and $5 \mu \mathrm{L} / \mathrm{mL}$ of N2), were added and the incubation was prolonged for 48 or $96 \mathrm{~h}$. The development of neurons-BMDCs interfaces was checked twice a day from the 6th to the 96th hour. Cocultures on coverslips were prolonged for at least $48 \mathrm{~h}$ to allow for a sufficient growth of neurites necessary for the installation of neuroimmune interfaces. At the end of the coculture, BMDCs were separated from neurons by a treatment of $0.2 \%$ EDTA (Sigma) at $37^{\circ} \mathrm{C}$ for $10 \mathrm{~min}$. Finally, coverslips were rinsed three times in PBS, air-dried, fixed in acetone at $4^{\circ} \mathrm{C}$ for $10 \mathrm{~min}$, and stored at $-20^{\circ} \mathrm{C}$ until use.

Infection of cells in culture

Scrapie-infected tissues were dissected from the brain of C57Bl/6 mice, which had been inoculated with the scrapie strain ME7, and which had developed the clinical signs of the disease. Phosphate buffer (Lonza) and phenyl-methylsulfonyl fluoride (PMSF) (Sigma) at $10 \mathrm{mM}$ were added to obtain $10 \% \mathrm{w} / \mathrm{v}$ homogenate. An equal volume of sterile PBS with 4\% sarkosyl (Fluka) was added before incubation under agitation at $37^{\circ} \mathrm{C}$ for $10 \mathrm{~min} ; 50 \mathrm{U} / \mathrm{mL}$ of Benzonase (Sigma) was introduced into the homogenate followed by incubation at $37^{\circ} \mathrm{C}$ for $30 \mathrm{~min}$. Preheated Phosphotungstic acid at $4 \%$ (diluted in $\mathrm{H}_{2} \mathrm{O}$ with $170 \mathrm{mM}$ of $\mathrm{MgCl}_{2}$ ) was added to obtain a final solution at $0.3 \%$. The homogenate was incubated at $37^{\circ} \mathrm{C}$ for $30 \mathrm{~min}$. Samples were centrifuged at $656 \times g$ for $30 \mathrm{~min}$. The $\mathrm{PrP}^{\mathrm{C}}$-containing supernatant was removed and the pellet containing $\operatorname{PrP}^{\mathrm{Sc}}$ was suspended in PBS-0.1\% sarkosyl. Homogenates (ME7PTA) were kept at $-80^{\circ} \mathrm{C}$ before utilization. Neurons, BMDCs, lymphocytes and fibroblasts were incubated with ME7-PTA, corresponding to $500 \mu \mathrm{g}$ of homogenate $/ \mathrm{mL}$, for $72 \mathrm{~h}$, and were then rinsed three times and centrifuged at $480 \times g$ for $3 \mathrm{~min}$. Cells, in culture or in coculture inoculated with ME7-PTA, were controlled after 6, 12, 24, 48 and $96 \mathrm{~h}$ for $\mathrm{PrP}^{\mathrm{Sc}}$ expression, cell-to-cell interactions and survival.

\section{Immunofluorescence}

After re-hydration, cultures on coverslips were incubated with a range of primary antibodies directed against DCs and neurons. These antibodies were directly bound to a fluorochrome or were revealed with a species-specific secondary antibody bearing a fluorescent label. Incubation with antibodies was performed at room temperature in the dark for $1 \mathrm{~h}$. DCs were detected with an anti-CD11c (1/ 400) (eBioscience) antibody directly labeled with fluorescein isothiocyanate (FITC) or with an anti-MHCII (1/100) (Chemicon) labeled with FITC or with an antibody directed against CD1d $(1 / 1,500)$ (eBioscience) coupled with biotin. Neurons and nerve fibers were labeled with an antibody directed against the intermediate neurofilaments: rabbit anti-mouse NF M 1/800 (200 kDa) (Chemicon). Prion proteins were detected with SAF 32 antibody (1/100) (J. Grassi). Nuclei were stained with ToPro3 (1/100 Invitrogen), a monomeric cyanine stain which allows ultrasensitive detection of double-stranded nucleic acids.

To test the general specificity of the antibodies used, samples were incubated with irrelevant antibodies, conjugated with fluorescein (FITC) and tetramethylrhodamine (TRITC). Negative controls were obtained by incubating samples with only secondary antibodies.

All samples were observed with a Leica SP2 confocal microscope. Cocultures were scanned on their best fluorescent zone $(5-7 \mu \mathrm{m})$, which was divided into $10-15$ sections. Each section was analyzed. Virtual colors were attributed for detection channels (green for immune cells and red for nerve fibers) and the merge (yellow). Two analytical methods were used to highlight neuroimmune interfaces: image analysis and spectral analysis of the color channels. These combined approaches allowed us to confirm contacts.

\section{Neurites outgrowth quantification}

The quantification of neurites outgrowth was evaluated with the neurites outgrowth quantification assay kit (Chemicon). 
Prior to initiation of neurites outgrowth the inserts were coated with $10 \mu \mathrm{g} / \mathrm{mL}$ of laminin (ICN Biomedicals) at $4{ }^{\circ} \mathrm{C}$ for $24 \mathrm{~h}$. After removing, without rinsing, inserts were placed into well containing $200 \mu \mathrm{L}$ of neurons-complete medium enriched with or without ME7-PTA, corresponding to a concentration of $500 \mu \mathrm{g}$ of homogenate $/ \mathrm{mL}$. Freshly isolated peripheral neurons were suspended in the insert. Following a neurites extension period of $96 \mathrm{~h}$, inserts were removed, gently rinsed in excess PBS and fixed in cold acetone at $4^{\circ} \mathrm{C}$ for $10 \mathrm{~min}$. Neurites were labeled with a rabbit anti-mouse NF M 1/800 (200 kDa) (Chemicon) revealed with an anti-rabbit Alexa 488 1/6,000 (Invitrogen). Standardized pictures $\left(8.1 \times 10^{3} \mu \mathrm{m}^{2}\right.$ at a resolution of $1,024 \times 1,024$ pixels) of neurites (virtual color: green) in each condition, obtained with a TCS SP2 confocal microscope, were treated by an image analyzer (QWIN, Leica) following this method: [number of green pixels]/ $\left[1,024^{2}\right.$ pixels]. Values obtained with control medium and infected medium were compared with a parametric $t$ test as implemented in the Statistica 8.0 software. Statistical significance was fixed at $p<0.05$. The experiment was repeated four times.

\section{Electron microscopy}

Cell pellets were incubated for $1 \mathrm{~h}$ at $4^{\circ} \mathrm{C}$, with primary SAF 32 (1/100) antibody diluted in phosphate buffer saline (PBS) and then washed in PBS. The cells were then incubated for $1 \mathrm{~h}$ in a biotinylated anti-mouse antibody (1/ $1,000)$. The secondary antibody was revealed for $1 \mathrm{~h}$ at $4{ }^{\circ} \mathrm{C}$ by a streptavidin-gold ( $10 \mathrm{~nm}$ gold particles, Aurion) complex diluted 1/10 in PBS. Following a wash in PBS, cells were fixed for $1 \mathrm{~h}$ at $4^{\circ} \mathrm{C}$ in a glutaraldehyde solution (2.5\%) in $0.1 \mathrm{M}$ cacodylate buffer (pH 7.4) buffer and then washed in the same buffer. The specimens were postfixed for $1 \mathrm{~h}$ in a mixture of $1 \% \mathrm{OsO}_{4}$ and $1.5 \% \mathrm{~K}_{4} \mathrm{Fe}(\mathrm{CN})_{6}$ in $0.1 \mathrm{M}$ cacodylate buffer ( $\mathrm{pH}$ 7.4), dehydrated in a graded series of alcohols and embedded in Epon 812 (Fluka, Belgium). The resin specimen blocks were trimmed, and 70- to 90-nm sections of selected area were cut on an ultramicrotome (Reichert, Ultracut E; Leica). Ultrathin sections were collected on 6,200 copper grids, stained with uranyl acetate solution in advance, with a Zeiss EM910 transmission electron microscope at $80 \mathrm{kV}$.

\section{Immunoblotting}

Tissue and cell homogenates $(10 \%, \mathrm{w} / \mathrm{v})$ were prepared on ice in lysis buffer $(100 \mathrm{mM} \mathrm{NaCl}, 10 \mathrm{mM}$ EDTA, $0.5 \%$ Nonidet P-40, $0.5 \%$ sodium deoxycholate, $10 \mathrm{mM}$ Tris, $0.1 \mathrm{mM}$ PMSF) at $\mathrm{pH}$ 7.4. Samples were treated at $37^{\circ} \mathrm{C}$ with Proteinase K (20 units/mg, Roche Diagnostics), using various concentration combinations for $1 \mathrm{~h}$ (concentration range for PK, $20-150 \mathrm{~g} / \mathrm{mL})$. PK stock solutions $(10 \mathrm{mg} /$ $\mathrm{mL}$ or higher) were prepared in storage buffer $(50 \%$ glycerol, $10 \mathrm{mM}$ Tris, $\mathrm{pH} 7.5,2.9 \mathrm{mg} / \mathrm{mL} \mathrm{CaCl}_{2}$ ). Small aliquots were prepared and stored at $-20^{\circ} \mathrm{C}$. Protease digestion was terminated by the addition of $2 \mathrm{mM}$ PMSF.

$10 \%$ tissue/cell homogenates were suspended in sample buffer (final concentration: 3\% SDS, $4 \% \quad \beta$-mercaptoethanol, $10 \%$ glycerol, $2 \mathrm{mM}$ EDTA, $62.5 \mathrm{mM}$ Tris, $\mathrm{pH}$ 6.8 ) and boiled for 8 min before loading. Protein samples, concentrated twice for immune cells, were separated within 12 or 15\% SDS-polyacrylamide gels (37.5:1 acrylamide:bisacrylamide) by a gel electrophoresis apparatus holding running minigels $(5.5 \mathrm{~cm})$ (Bio-Rad). Proteins were transferred to Immobilon $\mathrm{P}$ (Millipore) at $65 \mathrm{~V}$ for $2 \mathrm{~h}$, blocked with $10 \%$ non-fat milk in Tween Tris-buffered saline, $\mathrm{pH} 7.5$, and probed with the appropriate antibody. The monoclonal antibody SAF $32(1: 1,500)$ was used as the primary antibody. Immunoreactivity was visualized by enhanced chemiluminescence (ECL advance Bio-Rad) using the Bio-Rad ChemiDoc EQ system.

\section{Results}

Peripheral neurons and dendritic cells are connected by cytoplasmic extensions

We found that BMDCs in culture readily interact by the use of very thin cytoplasmic projections. These experiments indicate that large numbers of observed DCs could efficiently form membrane bridges of different lengths and diameters. Dendritic cells are connected by one to several membrane bridges containing MHCII molecules (Fig. 1) and actin-f (data not shown). In order to analyze the presence of in vitro neuroimmune interfaces, involving BMDCs and peripheral nerve fibers, cocultures were immunolabeled with an anti-CD11c-FITC and an antibody directed against neurofilament M subunit (NF M) coupled with TRITC. By confocal analysis, we observed numerous interfaces between DCs and nerve fibers or perikaryon (Fig. 2), subsequently confirmed by spectral analysis. In the coculture of at least 2 days, we observed cytoplasmic bridges between the two cell types. Further labeling with anti-MHCII-FITC antibody demonstrated that BMDCs and peripheral neurons are connected by extensions arising from dendritic cells (Fig. 3).

Dendritic cells and peripheral neurons express cellular PrP in culture

To confirm that both BMDCs and peripheral nerve cells conserve the same phenotype of $\operatorname{PrP}^{\mathrm{C}}$ expression in our model as in lymphoid organs and in order to verify that isolation from their microenvironment does not alter their $\operatorname{PrP}^{\mathrm{C}}$ 


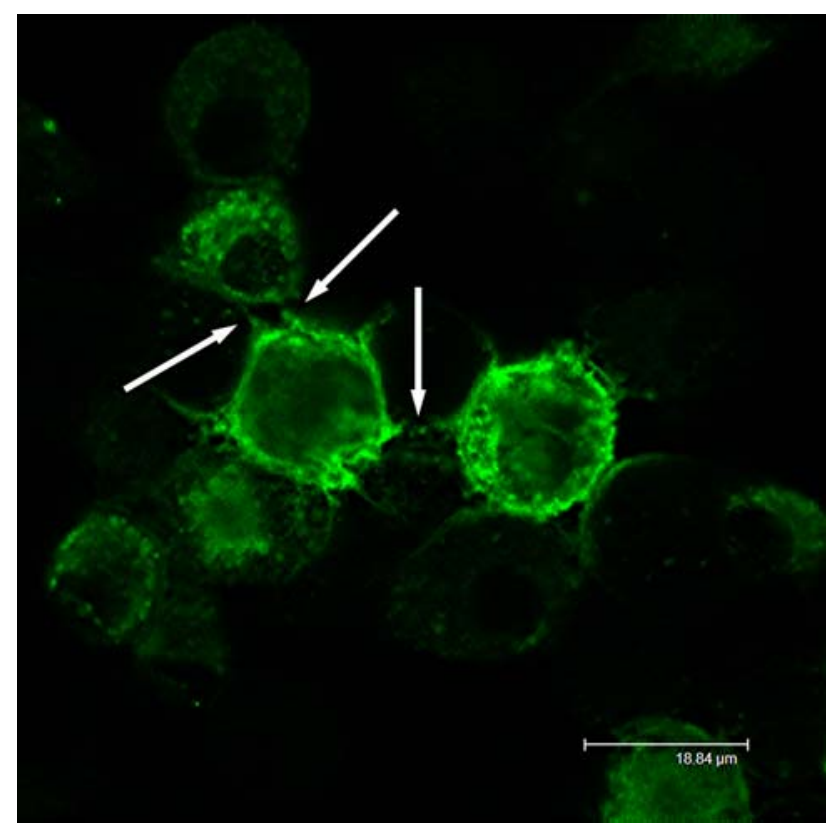

Fig. 1 Cell-to-cell connections between dendritic cells via cytoplasmic extensions. Confocal analysis and Z-stack snapshot of a network of cellular bridges in BMDCs labeled with anti-MHCII antibody coupled with FITC. The confocal analysis performed with Leica confocal software showing that the tubes are situated at different depths

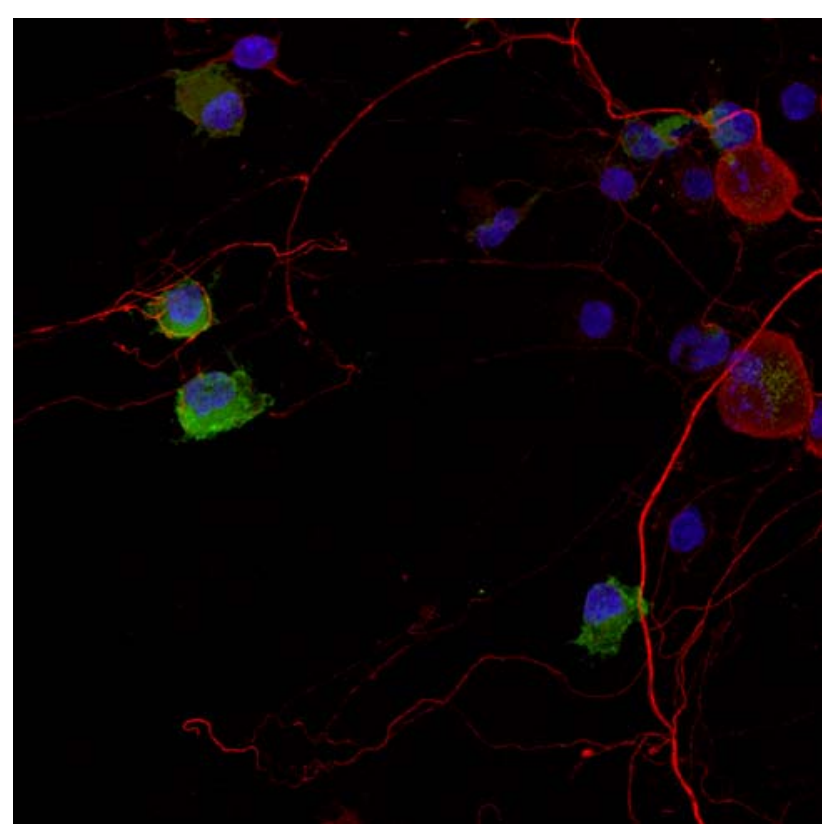

Fig. 2 Coculture of dendritic cells and peripheral neurons incubated for $48 \mathrm{~h}$. A triple immunolabeling analyzed by confocal microscopy allowed to identify cell nuclei in blue (labeled with ToPro-Alexa $633^{\circledR}$ ), BMDCs in green (labeled with anti-CD11c-FITC) and primary neurons in red (labeled with anti-NF M). Cytoplasmic connections between dendritic cells and peripheral nerve fibers appear in yellow. The image results from the overlapping of a series of 15 three-channel photographs

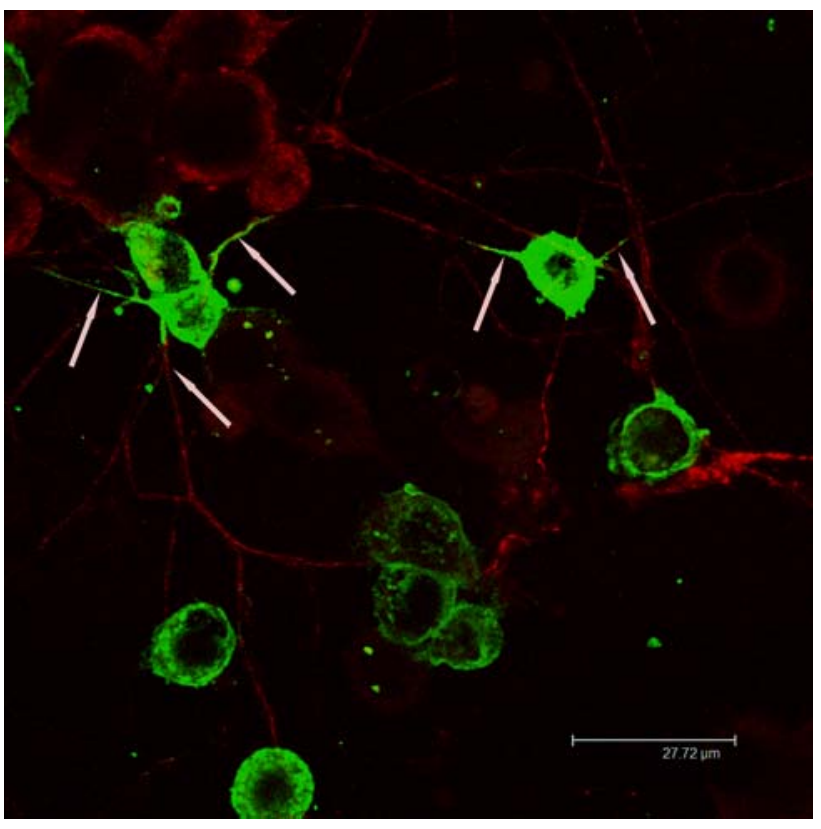

Fig. 3 Cell-to-cell connections between BMDCs and peripheral neurons via cytoplasmic extensions. Confocal analysis and Z-stack snapshot of a network of cellular bridges between BMDCs in green (MHCII) and primary peripheral neurons in red (NF M). Each dendritic cell emits several variable-sized extensions which connect neurites (arrows). The image results from the merging of a series of 12 two-channel photographs

expression, we studied the $\operatorname{PrP}^{\mathrm{C}}$ profile of the two cell types. The distribution of cytoplasmic and anchored $\mathrm{PrP}^{\mathrm{C}}$ was analyzed through immunofluorescence. Expression of cellular prion protein and MHCII molecules appeared simultaneously in BMDCs (Fig. 4). It suggests that specifically maturing DCs express $\operatorname{PrP}^{\mathrm{C}}$, as demonstrated in vivo (Martinez del et al. 2006; Dorban et al. 2007b). Freshly isolated peripheral neurons cultured for $48 \mathrm{~h}$ expressed $\mathrm{PrP}^{\mathrm{C}}$ within the perikaryon and neurites (Fig. 5). Membrane expression vanished during the enzymatic digestion and was recovered after the adherence on coverslip. Neurite outgrowth and $\mathrm{PrP}^{\mathrm{C}}$ expression within nervous extension appeared at once. The pattern of $\mathrm{PrP}^{\mathrm{C}}$ glycosylation expressed by cultured dendritic cells and peripheral neurons was studied through immunoblotting analysis. The BMDCs mainly showed a pattern of $\operatorname{PrP}^{\mathrm{C}}$ glycosylation with a monoglycosylated band, while peripheral neurons mostly expressed a diglycosylated $\operatorname{PrP}^{\mathrm{C}}$. Finally, the analysis of cell homogenates, containing the same amount of protein $(25 \mathrm{mg} / \mathrm{mL})$, showed that the level of $\operatorname{PrP}^{\mathrm{C}}$ expression in peripheral neurons is higher than in BMDCs (Fig. 6).

Detection of $\mathrm{PrP}^{\mathrm{Sc}}$ in infected BMDCs and peripheral neurons in culture

Furthermore, to determine whether DCs and neurons could acquire and retain prions, an ME7-PTA sample was 


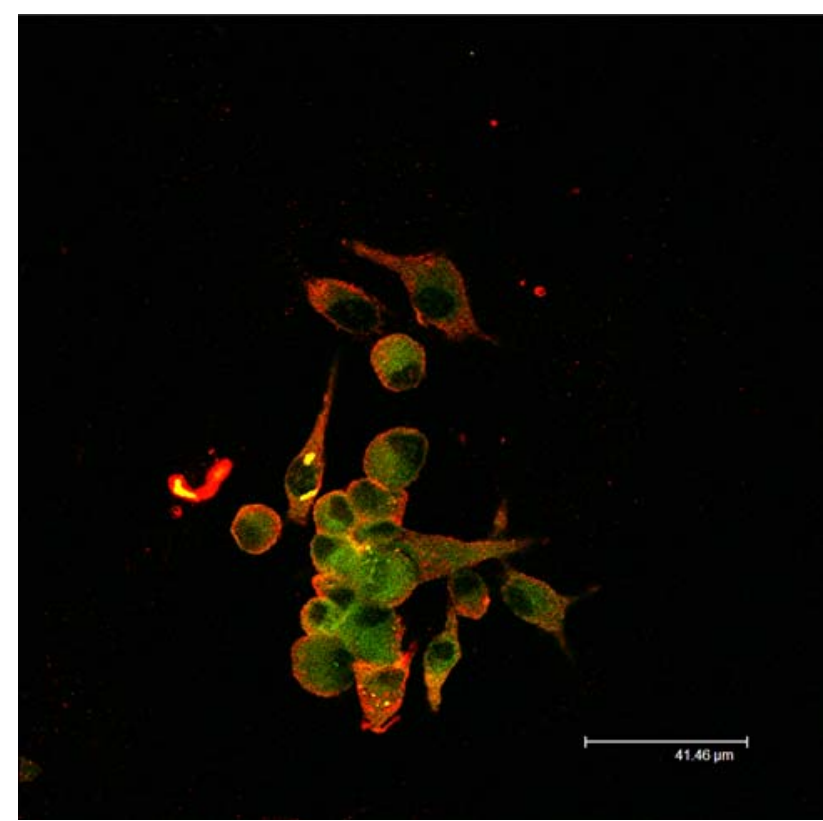

Fig. 4 Double immunolabeling of dendritic cells differentiated from bone marrow precursors with GM-CSF and Flt3-lg on the 11th day of the primo-culture. SAF 32 antibody directed against $\operatorname{PrP}^{\mathrm{C}}$ (red) and anti-MHCII antibody (green) were used

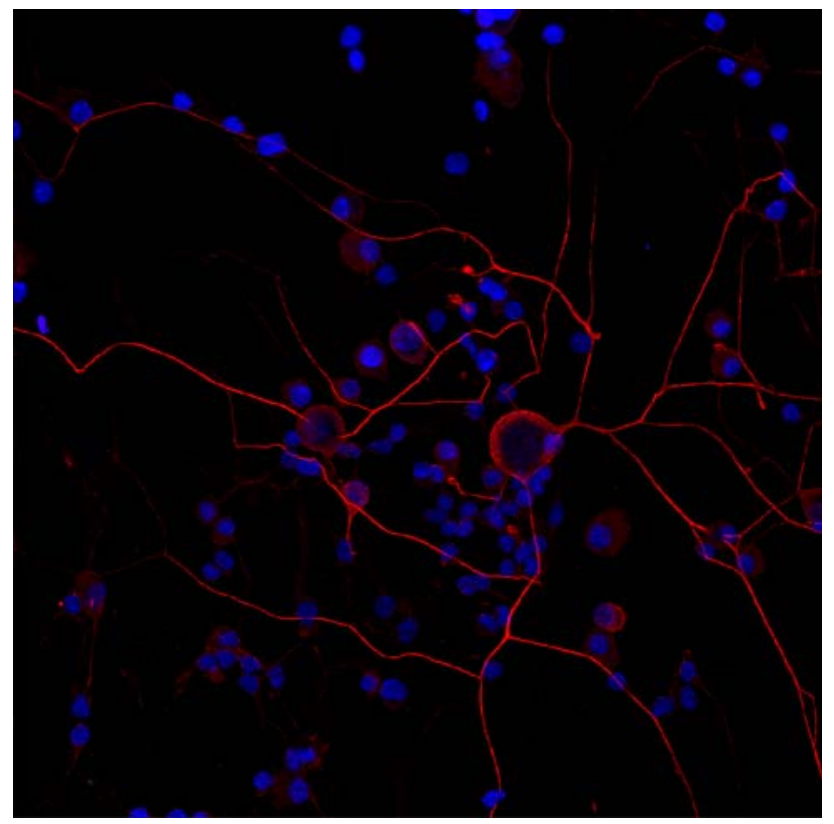

Fig. 5 Immunolabeling of neurons isolated from dorsal root ganglia and cultured on coverslip for $48 \mathrm{~h} . \operatorname{PrP}^{\mathrm{C}}($ red $)$, expressed in the perikaryon and in the neurites, was labeled with the SAF 32 antibody. Cells nuclei were stained with ToPro-Alexa $633^{\circledR}$ (blue)

incubated with each cell type. Detergent-insoluble, relatively proteinase K-resistant $\mathrm{PrP}^{\mathrm{Sc}}$ accumulations were detected in BMDCs and peripheral neurons lysates a few hours after the culture with the scrapie agent. Peripheral neurons were cultured for $48 \mathrm{~h}$ in the prions-free medium before the introduction of the scrapie sample. The detection of $\mathrm{PrP}^{\mathrm{Sc}}$ in neuron lysates showed no fluctuation up to $72 \mathrm{~h}$ of incubation (Fig. 7). Prions were also introduced in BMDC culture on day 9 of the primo-culture. Conversely to peripheral neurons, the level of $\mathrm{PrP}^{\mathrm{Sc}}$ detected in BMDC homogenates showed fluctuation between 24 and $48 \mathrm{~h}$ of culture: before $24 \mathrm{~h}$ of culture with ME7-PTA, the level of $\operatorname{PrP}^{\mathrm{Sc}}$ detected declined moderately and then increased from 24 to $48 \mathrm{~h}$. Stability reached from the 48th hour (Fig. 8). No $\mathrm{PrP}^{\mathrm{Sc}}$ accumulations were detected at any time in lysates from BMDCs and neurons treated with uninfected brain-PTA. Neither was uptake identified when lymphocytes (freshly isolated from murine spleen) or fibroblasts (3T3 cell line) were incubated with prions in vitro (Fig. 9).

\section{Influence of $\mathrm{PrP}^{\mathrm{Sc}}$ upon neurites outgrowth}

Given the suspected ability of $\operatorname{PrP}^{\mathrm{Sc}}$ and its peptides to influence the survival and the homeostasis of central neurons, the effect of prions was evaluated on their capacity of disturbing neurites outgrowth in a specific assay. The measure of axon and dendrites network constitutes a simple and consistent parameter to evaluate the health of the culture. Consequently, primary neurons isolated from the PNS were cultured within insert for $96 \mathrm{~h}$ and the development of neurites was continually observed. Adherence of the cells on coverslip started at the same time for both conditions and the growth of neurites was not delayed in the scrapieinfected medium. It stood out from the morphometry that no neurotoxicity or neurites outgrowth disorder was observed after comparing the culture of peripheral neurons with or without $\mathrm{PrP}^{\mathrm{Sc}}$ (Fig. 10). The absence of a negative effect of prions upon the neurites network is in accordance with in situ observations made on different species (Dorban et al. 2007a; Marruchella et al. 2009).

\section{Transmission of prions from infected BMDCs to neurons}

To examine the capacity of $\mathrm{PrP}^{\mathrm{Sc}}$-BMDCs to transmit prions, scrapie-infected BMDCs and peripheral neurons were cocultured for a period of 48 to $96 \mathrm{~h}$. The medium was replaced twice a day to avoid prion contamination by apoptotic BMDCs or by exosomes release. Aiming at obtaining a $\mathrm{PrP}^{\mathrm{Sc}}$-specific signal from the peripheral neurons, BMDCs and nervous cells were separated at the end of the coculture. The efficiency of the partition was confirmed by subsequent immunoblotting analysis under each cell homogenate, where the DC population expressed CD1d but not NF M. By contrast, neurons expressed NF M but no CD1d (data not shown). After $48 \mathrm{~h}$ of coculture with $\mathrm{PrP}^{\mathrm{Sc}}$-loaded BMDCs, peripheral neurons pretreated with $\mathrm{PK}$ were analyzed by Western blotting. Although the results showed that $\operatorname{PrP}^{\mathrm{C}}$ was successfully eliminated, $\operatorname{PrP}^{\mathrm{Sc}}$ remained undetectable 
Fig. 6 Immunoblotting analysis sion by bone marrow dendritic cells, peripheral neurons and tissue samples $(25 \mathrm{mg} / \mathrm{mL})$ were revealed with $\mathrm{SAF}$ antibody. Left BMDCs homogenate; center peripheral neurons homogenate and right brain homogenate. yellow arrow monoglycosylated $\mathrm{PrP}^{\mathrm{C}}$ and blue arrow unglycosylated $\operatorname{PrP}^{\mathrm{C}}$ of cellular prion protein expresbrain. $\operatorname{PrP}^{\mathrm{C}}$ from murine cell and Red arrow diglycosylated $\mathrm{PrP}^{\mathrm{C}}$,
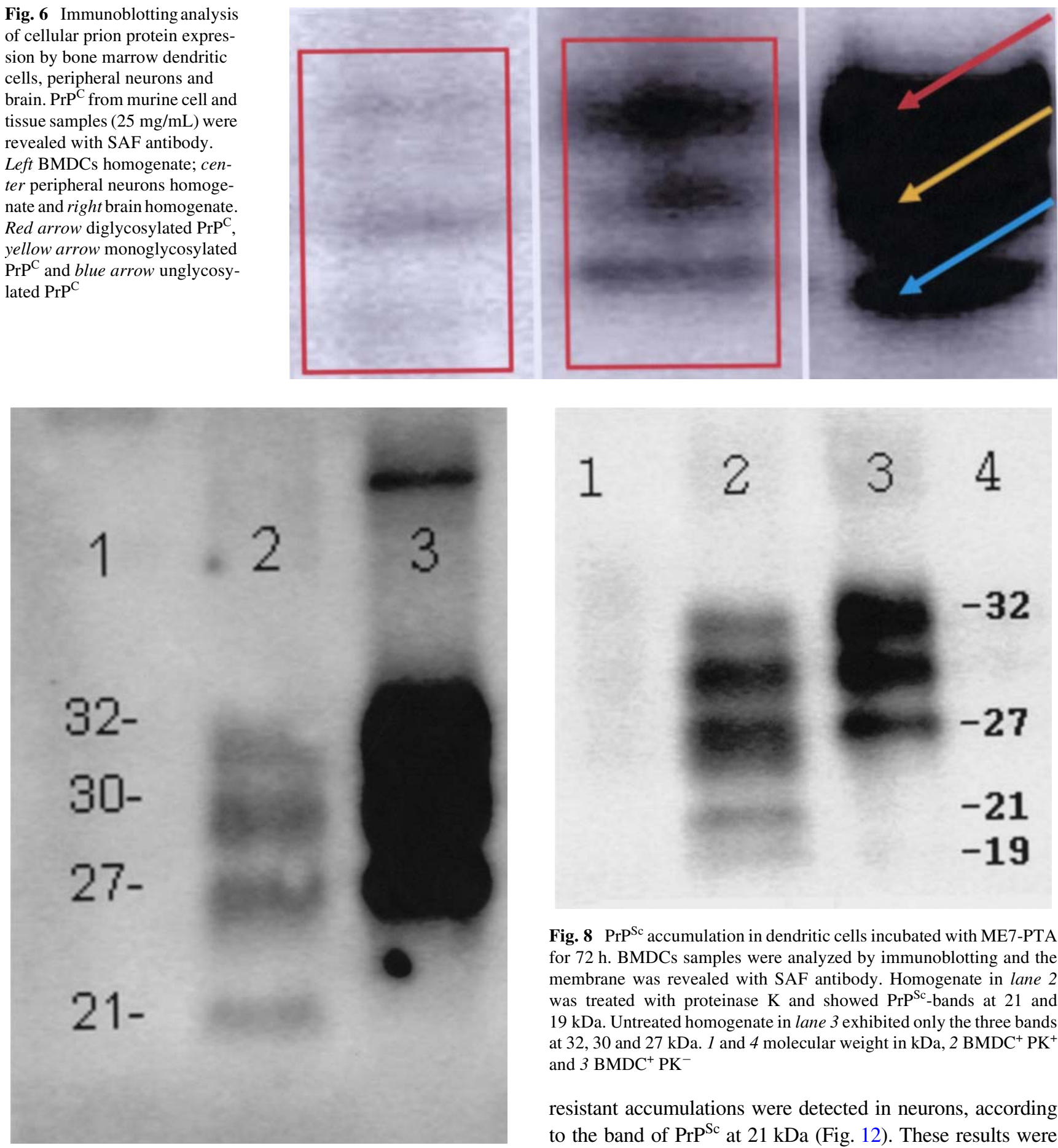

Fig. 7 Proteinase K-resistant PrP accumulation in peripheral neurons incubated with ME7-PTA for $72 \mathrm{~h}$. Peripheral neuron samples were analyzed by immunoblotting and the membrane was revealed with $\mathrm{SAF}$ antibody. Homogenate in lane 2 was treated with proteinase $\mathrm{K}$ and showed a typical $\operatorname{PrP}^{\mathrm{Sc}}$-band at $21 \mathrm{kDa}$. Untreated homogenate in lane 3 exhibited only the three bands at 32,30 and $27 \mathrm{kDa} .1$ molecular weight in $\mathrm{kDa}, 2$ Neurons ${ }^{+} \mathrm{PK}^{+}$and 3 Neurons ${ }^{+} \mathrm{PK}^{-}$

(Fig. 11). It suggested that neurons were uninfected by prions. Therefore, the coculture was extended to $96 \mathrm{~h}$. Subsequent to this lengthened time of incubation, proteinase- $\mathrm{K}$

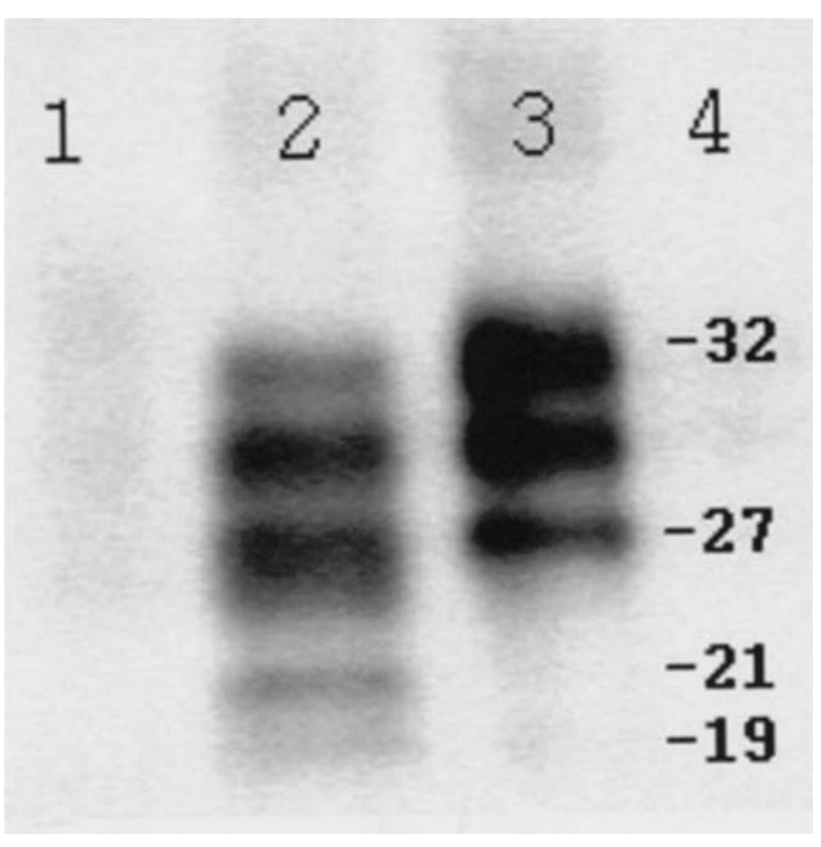

Fig. $8 \operatorname{PrP}^{\mathrm{Sc}}$ accumulation in dendritic cells incubated with ME7-PTA for $72 \mathrm{~h}$. BMDCs samples were analyzed by immunoblotting and the membrane was revealed with SAF antibody. Homogenate in lane 2 was treated with proteinase $\mathrm{K}$ and showed $\mathrm{PrP}^{\mathrm{Sc}}$-bands at 21 and $19 \mathrm{kDa}$. Untreated homogenate in lane 3 exhibited only the three bands at 32,30 and $27 \mathrm{kDa} .1$ and 4 molecular weight in $\mathrm{kDa}, 2 \mathrm{BMDC}^{+} \mathrm{PK}^{+}$ and $3 \mathrm{BMDC}^{+} \mathrm{PK}^{-}$

resistant accumulations were detected in neurons, according to the band of $\mathrm{PrP}^{\mathrm{Sc}}$ at $21 \mathrm{kDa}$ (Fig. 12). These results were qualitatively confirmed by cell-blotting (data not shown). Neurons cultured for $96 \mathrm{~h}$ with $\mathrm{PrP}^{\mathrm{Sc}}$-BMDCs or neurons directly incubated with ME7-PTA displayed the same electrophoretic profile after PK treatment.

$\operatorname{PrP}^{\mathrm{C}}$ expression is dispensable for the uptake of $\mathrm{PrP}^{\mathrm{Sc}}$ by dendritic cells

Primary cultures of dendritic cells were generated from $\mathrm{PrP}^{\text {nul }}$ mice to bear out that the presence of membrane-PrP 


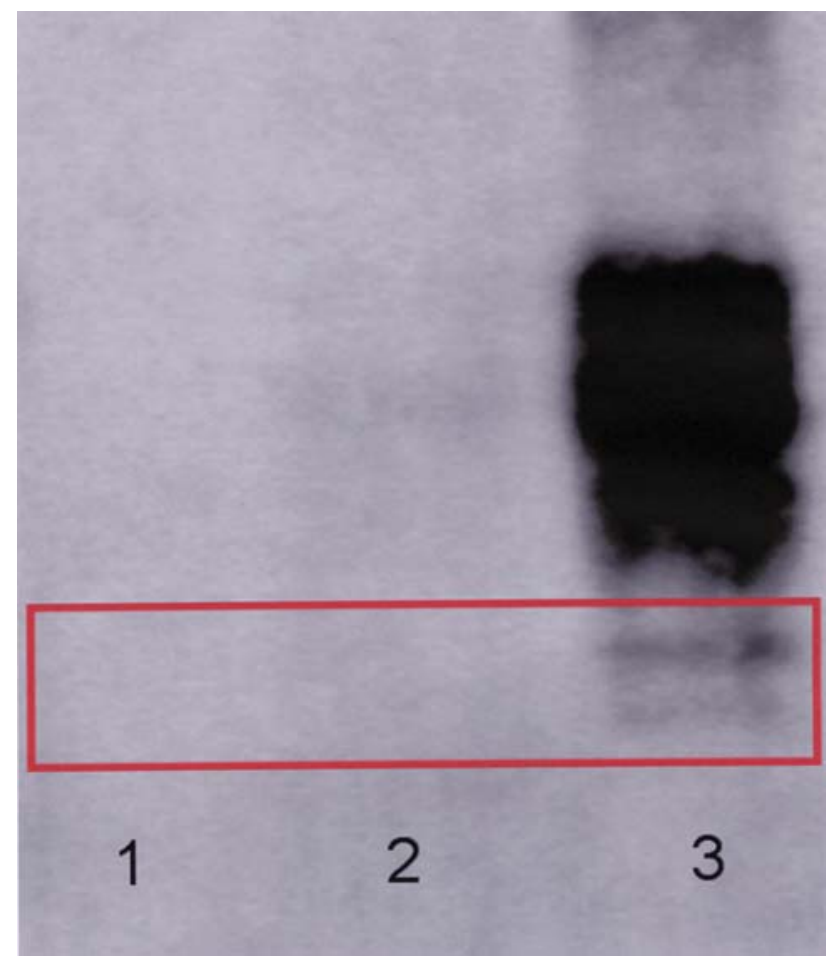

Fig. 9 Absence of $\mathrm{PrP}^{\mathrm{Sc}}$ retention by fibroblasts and lymphocytes cultured with scrapie homogenates for $72 \mathrm{~h}$. All samples were pretreated with proteinase $\mathrm{K}$ before the electrophoresis to detect $\operatorname{PrP}^{\mathrm{Sc}}$ deposit. Neither fibroblast samples nor lymphocyte samples analyzed by immunoblotting exhibit $\mathrm{PrP}^{\mathrm{Sc}}$-band $(21$ and $19 \mathrm{kDa})$ detected in scrapie-infected brain homogenate (red rectangle 1 Fibroblasts cultured with ME7-PTA $\left(\mathrm{PK}^{+}\right) .2$ Lymphocytes cultured with ME7-PTA $\left(\mathrm{PK}^{+}\right) .3$ ME7-infected brain $\left(\mathrm{PK}^{+}\right)$

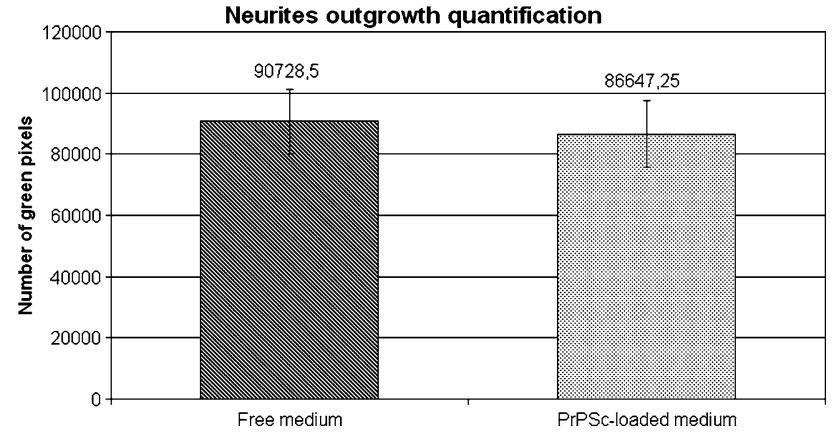

Fig. 10 Prions introduced in the neurons medium do not influence neurites outgrowth. The development of the neurites network, in scrapie and control conditions, was evaluated by a specific in vitro assay. The number of green pixels, which highlights NF M immunolabeling, was counted on standardized images obtained by confocal analysis (as described in "Methods"). No significant statistical difference appeared after comparing the values acquired in the two experimental conditions. The average is indicated on the top of each histogram. SD: 10,641.04 (free medium) and 10,786.49 ( $\mathrm{PrP}^{\mathrm{Sc}}$-loaded medium). The experiment was repeated four times

is needless to load BMDCs with $\operatorname{PrP}^{\mathrm{Sc}}$. In this condition neither immature nor mature BMDCs express $\operatorname{PrP}^{\mathrm{C}}$. The ME7-PTA was introduced in BMDC culture on day 9 of the

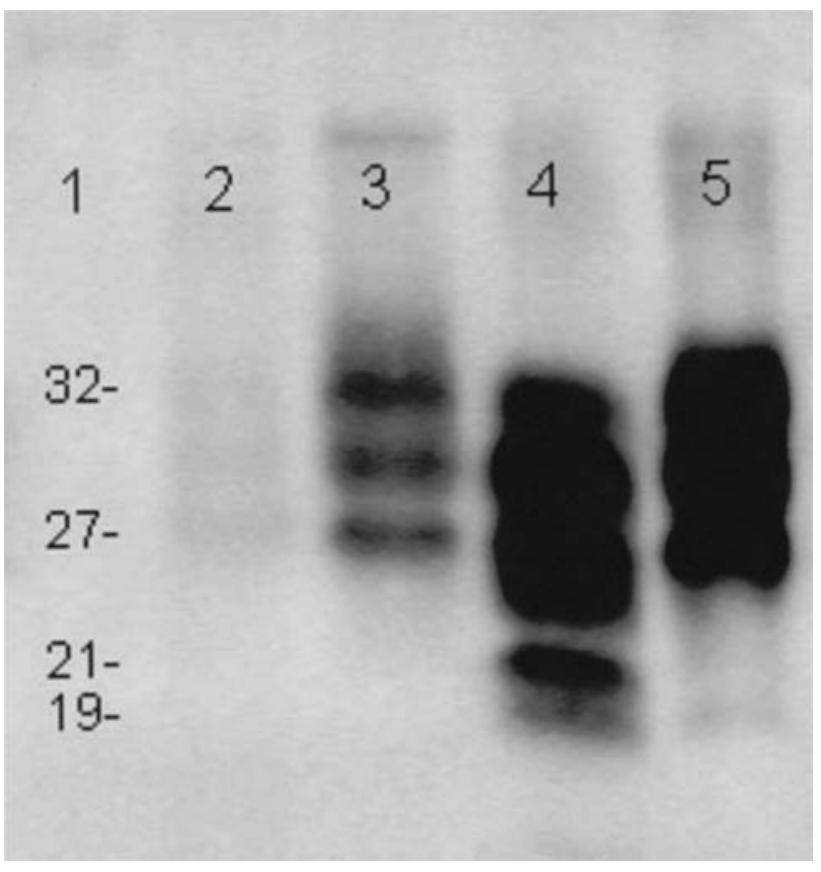

Fig. 11 Absence of prion accumulation in peripheral neurons from dorsal root ganglia cocultured in the presence of infected-BMDCs for $48 \mathrm{~h}$. Samples in lanes 2 and 4 were treated with proteinase K. Neurons sample in lane 2 was treated with proteinase $\mathrm{K}$ and showed no PrP-band. Infected-brain sample in lane 4 was treated with proteinase $\mathrm{K}$ and showed typical $\mathrm{PrP}^{\mathrm{Sc}}$-bands at 21 and $19 \mathrm{kDa}$. Untreated neurons sample in lane 3 and infected brain sample in lane 5 exhibited only the three bands at 32,30 and $27 \mathrm{kDa}$. 1 molecular weight in $\mathrm{kDa}$, 2 Neurons (cultivated with infected-BMDCs) $\mathrm{PK}^{+}, 3$ Neurons (cultivated with infected-BMDCs) $\mathrm{PK}^{-}, 4$ ME7-infected brain $\mathrm{PK}^{+}$and 5 ME7-infected brain $\mathrm{PK}^{-}$

primo-culture for $48 \mathrm{~h}$. Firstly, the ability of dendritic cells to take up $\operatorname{PrP}^{\mathrm{Sc}}$ was confirmed by the detection of ME7PTA deposits by immunoblots (Fig. 13i). Secondly, we analyzed the cellular localization of $\operatorname{PrP}^{\mathrm{Sc}}$ within BMDCs. No membrane deposits of $\operatorname{PrP}^{\mathrm{Sc}}$ were detected using Nomarski interference and fluorescence immunocytochemistry (Fig. 13f). This last result was attested with a better sensitivity, using pre-embedding immunogold cytochemistry, by electron microscopy analysis (Fig. 13c). On the contrary, $\operatorname{PrP}^{\mathrm{Sc}}$ accumulations were detected in the intracellular compartment of BMDCs. Immunoblots show that BMDCs have internalized $\operatorname{PrP}^{\mathrm{Sc}}$ (Fig. 13i).

\section{Discussion}

The hypothesis of the implication of DCs-peripheral nerve fibers interfaces in the pathogenesis of prion diseases originally resulted from in vivo studies that described neuroimmune connections in scrapie-infected lymphoid organs (Defaweux et al. 2005; Ma et al. 2007; Dorban et al. 2007a). In contrast to other models based on neuroblastoma 


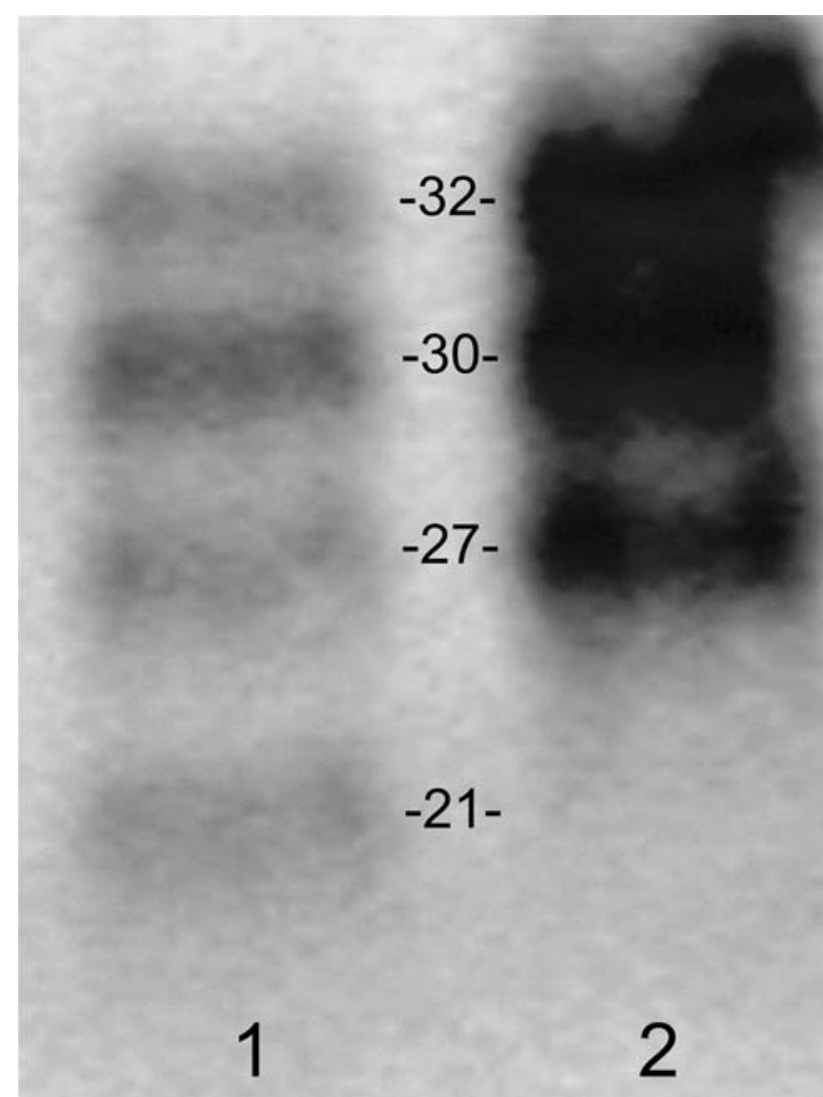

Fig. $12 \mathrm{PrP}^{\mathrm{Sc}}$ accumulation in peripheral neurons cocultured with scrapie-infected BMDCs for $96 \mathrm{~h}$. Neurons sample in lane 1 was treated with proteinase $\mathrm{K}$ and showed a typical $\mathrm{PrP}^{\mathrm{Sc}}$-band at $21 \mathrm{kDa}$. Untreated homogenate in lane 2 exhibited only the three bands at 32, 30 and $27 \mathrm{kDa}$

(Luhr et al. 2002, 2004) our model used peripheral primary neurons that were infected in vivo after oral scrapie challenge (Beekes and McBride 2007). Thus our model specifically targeted a cell-to-cell transmission of $\mathrm{PrP}^{\mathrm{Sc}}$ (Caughey and Baron 2006) from the immune system to the PNS, hypothetically at the genesis of the prion peripheral neuroinvasion (Kimberlin and Walker 1989). In this purpose, the dissemination of prions via infected apoptotic cells or cellular fragments was limited by frequent washing. Therefore, most of the potentially infected exosomes (Fevrier et al. 2004; Couzin 2005) generated by BMDCs were removed in order to support cell-to-cell infection.

The molecular composition of neuroimmune interfaces throughout close contacts and their implications in prion pathogenesis remains unclear. In addition to synaptic and ligand-receptor interaction, a new type of inter-cellular communication was discovered a few years ago, that is based on de novo formation of membranous nanotubes between cells. These structures, referred to as tunneling nanotubes (TNT) were shown to facilitate the transport of various cellular components (Rustom et al. 2004). Some authors have hypothesized that some small pathogens, such as prions, can be disseminated by these exchange processes (Caughey and Baron 2006; Gousset et al. 2009). Several arguments attest of the implication of TNT in prions spreading. (1) Gousset et al. demonstrated that BMDCs can transmit prions to primary neurons from the CNS (Gousset et al. 2009). (2) Peripheral neurons are particularly competent to generate TNT (Rustom et al. 2004). (3) In this study we have showed thin cytoplasmic extensions, arising from BMDCs, which connected dendritic cells and primary neurons.

In our model we demonstrate that, after $96 \mathrm{~h}$ of co-culture with scrapie-infected BMDCs, neurons have accumulated $\mathrm{PrP}^{\mathrm{Sc}}$. Before this point in time, immuno-blotting analysis did not reveal any $\mathrm{PrP}^{\mathrm{Sc}}$ in nerve cells. This insufficient amount of prion protein could result from a slow rate of transfer. As a result, after $48 \mathrm{~h}$ the contacts between BMDCs and neurons were recent and the quantity of prions accumulated in neurons was undetectable by Western-blotting. This assumption implicates that the proteins detected in peripheral neurons after $96 \mathrm{~h}$ were ME7-PTA prions previously introduced into BMDCs medium. In this case no replication of $\operatorname{PrP}^{\mathrm{Sc}}$ occurred. Alternatively the infection of neurons is rapid and requires a small number of prions but $\mathrm{PrP}^{\mathrm{Sc}}$ has to be replicated by nerve cells. Following this hypothesis the proteins highlighted after $96 \mathrm{~h}$ were newly synthesized prions.

Despite cellular PrP expression is necessary for the replication of prions (Bueler et al. 1993), it has been previously demonstrated that the retention of $\mathrm{PrP}^{\mathrm{Sc}}$ is facilitated when host $\operatorname{PrP}^{\mathrm{C}}$ and the infectious strain share a similar glycosylation profile (DeArmond et al. 1999). In this study we infected both peripheral neurons and BMDCs with a strongly diglycosylated prion strain (Kuczius et al. 1998). Peripheral neurons, displaying a mainly diglycosylated $\mathrm{PrP}^{\mathrm{C}}$, and ME7 scrapie strain share a similar pattern of glycosylation. Therefore, this accumulation appears to be in agreement with the theory of DeArmond et al. On the contrary, BMDCs with a monoglycosylated $\mathrm{PrP}^{\mathrm{C}}$ profile can also be loaded with a diglycosylated prion strain. The infection of dendritic cells suggests alternative explanations. As it has been earlier described in neurons (Nielsen et al. 2004), prion inoculation in the BMDCs medium could stimulate diglycosylation of newly synthesized $\operatorname{PrP}^{\mathrm{C}}$, which could enhance $\operatorname{PrP}^{\mathrm{Sc}}$ uptake. Our results, based on $\operatorname{PrP}^{\text {nul }}$ strategy, prove that BMDCs can retain prions random mechanism, by endocytosis, or via a specific mechanism, such as specific lectins or receptors, which are both independent of $\mathrm{PrP}^{\mathrm{C}}$ expression. It has been showed that $\mathrm{C} 1 \mathrm{q}$ participates in $\mathrm{PrP}^{\mathrm{Sc}}$ uptake and prion-loaded DCs express one of the $\mathrm{C} 1 \mathrm{q}$ receptors, calreticulin (Mitchell et al. 2007; Flores-Langarica et al. 2009). The 37/67-kDa laminin receptor expressed at the cell surface can also act in 
Fig. $13 \mathrm{PrP}^{\mathrm{Sc}}$ accumulation in BMDCs, differentiated from $\mathrm{PrP}^{\text {nul }}$ mice, incubated with ME7-PTA for $72 \mathrm{~h}$. Dendritic cells deprived of cellular prion protein were exposed to medium only (a, d, g), uninfected-PTA $(\mathbf{b}, \mathbf{e}, \mathbf{h})$, or ME7-PTA $(\mathbf{c}, \mathbf{f}, \mathbf{i})$ and labeled with SAF 32 antibody and analyzed by electron microscopy (a-c). Nomarski interference and fluorescence (d-f), and immunoblotting (g-i). BMDCs exhibit no membrane $\mathrm{PrP}^{\mathrm{Sc}}$ when incubated with prions for $72 \mathrm{~h}(\mathbf{c}, \mathbf{f})$. As well as in control conditions $(\mathbf{a}, \mathbf{b}$ and $\mathbf{d}-\mathbf{e})$ no gold $10 \mathrm{~nm}$-particle was detected on the surface of dendritic cells (c) and no red dye was highlighted by immunofluorescence (f). Conversely $\mathrm{PrP}^{\mathrm{Sc}}$ was identified when intracellular proteins were analyzed (i). Control conditions $(\mathbf{g}, \mathbf{h})$ were PrP-negative

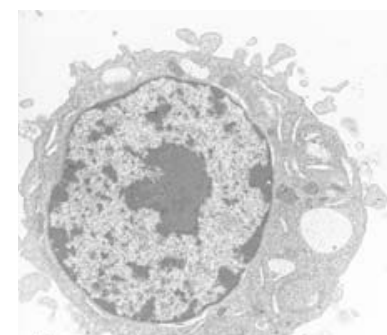

A

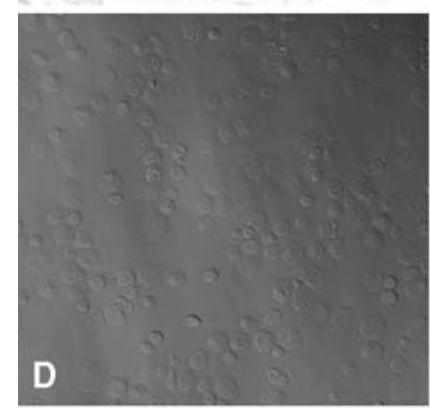

G

$\mathrm{PrP}^{\mathrm{Sc}}$ retention (Gauczynski et al. 2006). Recently, evidences have been demonstrated that the interactions of $\mathrm{PrP}^{\mathrm{Sc}}$ and laminin receptor occur on the cell surface and also in perinuclear compartments suggesting a putative role of LRP/LR in the trafficking of $\operatorname{PrP}^{\mathrm{Sc}}$ molecules (Nikles et al. 2008). An up to date study has beard out that lipids rafts are involved in $\operatorname{PrP}$ internalization and are associated with prion protein in the cytoplasm (Sarnataro et al. 2009).

Although prions cause neuronal death in the CNS, we showed here that prions introduced in the culture of peripheral neurons did not induce neurotoxicity or neurites outgrowth disturbance. Various explanations can be put forward for this. (a) Microglial cells seem to be implicated in the process of neurodegeneration via IL- $1 \beta$ and IL-6 secretion (Priller et al. 2006; Pasquali et al. 2006) and they are associated with amyloid accumulation (Rezaie and Lantos 2001). Our system did not contain any microglial cells and could therefore have been protected from neurotoxicity. (b) Within the neurons of the CNS, $\operatorname{PrP}^{\mathrm{Sc}}$ was localized in two different compartments: LAMP-1 and flotillin1 vesicles, whereas in the PNS prions were only located in LAMP-1 vesicles (Pimpinelli et al. 2005; Leblanc et al. 2006). This supplementary compartment in the CNS could
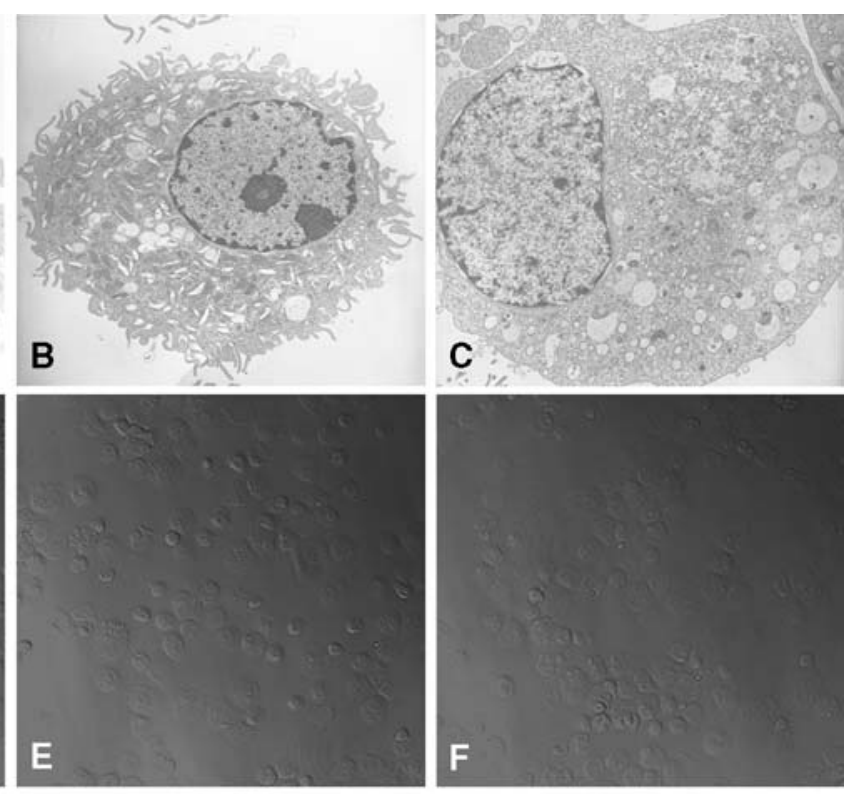

H

I explain the lack of neurotoxicity in our system using peripheral neurons. Indeed flotillin1 interacts with neuroglobin, which protects neurons from oxidative stress (Wakasugi et al. 2004). $\mathrm{PrP}^{\mathrm{Sc}}$ could disturb the protective effect of neuroglobin and expose central neurons to oxidative stress. (c) Fatty-acid components of the plasma membrane influence apoptosis after prions inoculation. Neuroblastoma pretreated with palmitic acid and infected with the $\operatorname{PrP}_{106-126}$ were found to be much more sensitive than untreated cells (Dupiereux et al. 2006). A possible variation in the composition of membrane fatty-acids and their relative percentage in peripheral and central neurons could explain the variation in $\mathrm{PrP}^{\mathrm{Sc}}$ sensitivity.

Our system of coculture demonstrated that infected DCs are competent to transmit $\operatorname{PrP}^{\mathrm{Sc}}$ to primary peripheral neurons by cell-to-cell cytonemes and is additional of the study of Gousset et al. (Gousset et al. 2009). Besides, this system could be use to investigate the species barrier using BSE and VCJD strains. In order to highlight molecular actors responsible for prion capture and transmission, our model could also be used with knockout DCs for complement factors. Finally, our model could be a powerful system to test molecules that are potential candidates for reducing or stopping prion propagation. 
Acknowledgments This study was supported by Région Wallone and EU research Immuno TSE project number QLK5-CT-2002-01044. Primary cultures of BMDCs from $\mathrm{B} 6$ mice and $\mathrm{PrP}^{-1-}$ mice were kindly provided by Christian Villiers, Inserm U823, La Tronche. SAF antibodies were kindly provided by Jacques Grassi CEA Saclay, Gif-sur-Yvette.

\section{References}

Andreoletti O, Berthon P, Marc D, Sarradin P, Grosclaude J, van KL, Schelcher F, Elsen JM, Lantier F (2000) Early accumulation of $\operatorname{PrP}(\mathrm{Sc})$ in gut-associated lymphoid and nervous tissues of susceptible sheep from a Romanov flock with natural scrapie. J Gen Virol 81:3115-3126

Aucouturier P, Geissmann F, Damotte D, Saborio GP, Meeker HC, Kascsak R, Kascsak R, Carp RI, Wisniewski T (2001) Infected splenic dendritic cells are sufficient for prion transmission to the CNS in mouse scrapie. J Clin Invest 108:703-708

Beekes M, McBride PA (2007) The spread of prions through the body in naturally acquired transmissible spongiform encephalopathies. FEBS J 274:588-605

Berthier R, Martinon-Ego C, Laharie AM, Marche PN (2000) A twostep culture method starting with early growth factors permits enhanced production of functional dendritic cells from murine splenocytes. J Immunol Methods 239:95-107

Blattler T, Brandner S, Raeber AJ, Klein MA, Voigtlander T, Weissmann C, Aguzzi A (1997) PrP-expressing tissue required for transfer of scrapie infectivity from spleen to brain. Nature 389:69-73

Bruce ME, McBride PA, Farquhar CF (1989) Precise targeting of the pathology of the sialoglycoprotein, PrP, and vacuolar degeneration in mouse scrapie. Neurosci Lett 102:1-6

Bueler H, Aguzzi A, Sailer A, Greiner RA, Autenried P, Aguet M, Weissmann C (1993) Mice devoid of PrP are resistant to scrapie. Cell 73:1339-1347

Caughey B, Baron GS (2006) Prions and their partners in crime. Nature 443:803-810

Chiocchetti R et al (2008) Anatomical evidence for ileal Peyer's patches innervation by enteric nervous system: a potential route for prion neuroinvasion? Cell Tissue Res 332(2):185-194

Cohen FE, Prusiner SB (1998) Pathologic conformations of prion proteins. Annu Rev Biochem 67:793-819

Cordier-Dirikoc S, Chabry J (2008) Temporary depletion of CD11c+ dendritic cells delays lymphoinvasion after intraperitonal scrapie infection. J Virol 82:8933-8936

Couzin J (2005) Cell biology: the ins and outs of exosomes. Science 308:1862-1863

DeArmond SJ, Qiu Y, Sanchez H, Spilman PR, Ninchak-Casey A, Alonso D, Daggett V (1999) PrPc glycoform heterogeneity as a function of brain region: implications for selective targeting of neurons by prion strains. J Neuropathol Exp Neurol 58:1000-1009

Defaweux V, Dorban G, Demonceau C, Piret J, Jolois O, Thellin O, Thielen C, Heinen E, Antoine N (2005) Interfaces between dendritic cells, other immune cells, and nerve fibres in mouse Peyer's patches: potential sites for neuroinvasion in prion diseases. Microsc Res Tech 66:1-9

Dorban G, Defaweux V, Demonceau C, Flandroy S, Van Lerberghe PB, Falisse-Poirrier N, Piret J, Heinen E, Antoine N (2007a) Interaction between dendritic cells and nerve fibres in lymphoid organs after oral scrapie exposure. Virchows Arch 451:10571065

Dorban G et al (2007b) Oral scrapie infection modifies the homeostasis of Peyer's patches' dendritic cells. Histochem Cell Biol 128:243251
Dupiereux I, Zorzi W, Rachidi W, Zorzi D, Pierard O, Lhereux B, Heinen E, Elmoualij B (2006) Study on the toxic mechanism of prion protein peptide 106-126 in neuronal and non neuronal cells. J Neurosci Res 84:637-646

Fevrier B, Vilette D, Archer F, Loew D, Faigle W, Vidal M, Laude H, Raposo G (2004) Cells release prions in association with exosomes. Proc Natl Acad Sci USA 101:9683-9688

Flores-Langarica A, Sebti Y, Mitchell DA, Sim RB, MacPherson GG (2009) Scrapie pathogenesis: the role of complement C1q in scrapie agent uptake by conventional dendritic cells. J Immunol 182:1305-1313

Gauczynski S, Nikles D, El-Gogo S, Papy-Garcia D, Rey C, Alban S, Barritault D, Lasmezas CI, Weiss S (2006) The 37-kDa/67-kDa laminin receptor acts as a receptor for infectious prions and is inhibited by polysulfated glycanes. J Infect Dis 194:702-709

Gousset K et al (2009) Prions hijack tunnelling nanotubes for intercellular spread. Nat Cell Biol 11:328-336

Heppner FL, Christ AD, Klein MA, Prinz M, Fried M, Kraehenbuhl JP, Aguzzi A (2001) Transepithelial prion transport by M cells. Nat Med 7:976-977

Huang FP, MacPherson GG (2004) Dendritic cells and oral transmission of prion diseases. Adv Drug Deliv Rev 56:901-913

Huang FP, Farquhar CF, Mabbott NA, Bruce ME, MacPherson GG (2002) Migrating intestinal dendritic cells transport $\operatorname{PrP}(\mathrm{Sc})$ from the gut. J Gen Virol 83:267-271

Iwata $\mathrm{N}$ et al (2006) Distribution of $\operatorname{PrP}(\mathrm{Sc})$ in cattle with bovine spongiform encephalopathy slaughtered at abattoirs in Japan. Jpn J Infect Dis 59:100-107

Jeffrey M et al (2006) Transportation of prion protein across the intestinal mucosa of scrapie-susceptible and scrapie-resistant sheep. J Pathol 209:4-14

Kelsall BL, Rescigno M (2004) Mucosal dendritic cells in immunity and inflammation. Nat Immunol 5:1091-1095

Kimberlin RH, Walker CA (1989) The role of the spleen in the neuroinvasion of scrapie in mice. Virus Res 12:201-211

Kratzel C, Mai J, Madela K, Beekes M, Kruger D (2007) Propagation of scrapie in peripheral nerves after footpad infection in normal and neurotoxin exposed hamsters. Vet Res 38:127-139

Kuczius T, Haist I, Groschup MH (1998) Molecular analysis of bovine spongiform encephalopathy and scrapie strain variation. J Infect Dis 178:693-699

Leblanc P, Alais S, Porto-Carreiro I, Lehmann S, Grassi J, Raposo G, Darlix JL (2006) Retrovirus infection strongly enhances scrapie infectivity release in cell culture. EMBO J 25:2674-2685

Luhr KM, Wallin RP, Ljunggren HG, Low P, Taraboulos A, Kristensson $K$ (2002) Processing and degradation of exogenous prion protein by $\mathrm{CD} 11 \mathrm{c}(+)$ myeloid dendritic cells in vitro. J Virol 76:12259-12264

Luhr KM, Nordstrom EK, Low P, Ljunggren HG, Taraboulos A, Kristensson K (2004) Scrapie protein degradation by cysteine proteases in CD11c+ dendritic cells and GT1-1 neuronal cells. J Virol 78:4776-4782

Ma B, von WR, Lindenmaier W, Dittmar KE (2007) Immmunohistochemical study of the blood and lymphatic vasculature and the innervation of mouse gut and gut-associated lymphoid tissue. Anat Histol Embryol 36:62-74

Marruchella G et al (2007) Enteroglial and neuronal involvement without apparent neuron loss in ileal enteric nervous system plexuses from scrapie-affected sheep. J Gen Virol 88:2899-2904

Marruchella G et al (2009) Ileal tract and Peyer's patch innervation in scrapie-free versus scrapie-affected ovines. Arch Virol 154:709714

Martinez del HG, Lopez-Bravo M, Metharom P, Ardavin C, Aucouturier $\mathrm{P}$ (2006) Prion protein expression by mouse dendritic cells is restricted to the nonplasmacytoid subsets and correlates with the maturation state. J Immunol 177:6137-6142 
Mitchell DA, Kirby L, Paulin SM, Villiers CL, Sim RB (2007) Prion protein activates and fixes complement directly via the classical pathway: implications for the mechanism of scrapie agent propagation in lymphoid tissue. Mol Immunol 44:2997-3004

Nielsen D, Gyllberg H, Ostlund P, Bergman T, Bedecs K (2004) Increased levels of insulin and insulin-like growth factor- 1 hybrid receptors and decreased glycosylation of the insulin receptor alpha- and beta-subunits in scrapie-infected neuroblastoma N2a cells. Biochem J 380:571-579

Nikles D, Vana K, Gauczynski S, Knetsch H, Ludewigs H, Weiss S (2008) Subcellular localization of prion proteins and the $37 \mathrm{kDa} /$ $67 \mathrm{kDa}$ laminin receptor fused to fluorescent proteins. Biochim Biophys Acta 1782:335-340

Pasquali $P$ et al (2006) Intracerebral administration of interleukin-12 (IL-12) and IL-18 modifies the course of mouse scrapie. BMC Vet Res 2:37

Pimpinelli F, Lehmann S, Maridonneau-Parini I (2005) The scrapie prion protein is present in flotillin-1-positive vesicles in centralbut not peripheral-derived neuronal cell lines. Eur J Neurosci 21:2063-2072

Priller J, Prinz M, Heikenwalder M, Zeller N, Schwarz P, Heppner FL, Aguzzi A (2006) Early and rapid engraftment of bone marrowderived microglia in scrapie. J Neurosci 26:11753-11762

Raymond CR, Aucouturier P, Mabbott NA (2007) In vivo depletion of $\mathrm{CD} 11 \mathrm{c}+$ cells impairs scrapie agent neuroinvasion from the intestine. J Immunol 179:7758-7766
Rezaie P, Lantos PL (2001) Microglia and the pathogenesis of spongiform encephalopathies. Brain Res Brain Res Rev 35:55-72

Rustom A, Saffrich R, Markovic I, Walther P, Gerdes HH (2004) Nanotubular highways for intercellular organelle transport. Science 303:1007-1010

Rybner-Barnier C et al (2006) Processing of the bovine spongiform encephalopathy-specific prion protein by dendritic cells. J Virol 80:4656-4663

Sarnataro D, Caputo A, Casanova P, Puri C, Paladino S, Tivodar SS, Campana V, Tacchetti C, Zurzolo C (2009) Lipid rafts and clathrin cooperate in the internalization of PrP in epithelial FRT cells. PLoS One 4:e5829

Sigurdson CJ, Spraker TR, Miller MW, Oesch B, Hoover EA (2001) $\operatorname{PrP}(\mathrm{CWD})$ in the myenteric plexus, vagosympathetic trunk and endocrine glands of deer with chronic wasting disease. J Gen Virol 82:2327-2334

van Keulen LJ, Schreuder BE, Vromans ME, Langeveld JP, Smits MA (2000) Pathogenesis of natural scrapie in sheep. Arch Virol Suppl (16):57-71

van Keulen LJ, Vromans ME, van Zijderveld FG (2002) Early and late pathogenesis of natural scrapie infection in sheep. APMIS 110:23-32

Wakasugi K, Nakano T, Kitatsuji C, Morishima I (2004) Human neuroglobin interacts with flotillin-1, a lipid raft microdomainassociated protein. Biochem Biophys Res Commun 318:453-460 